\title{
The internal structure of destination visitation model and implications for image management
}

\author{
Babu P George, $\mathrm{PhD}^{*}$ \\ Services Area Alaska Pacific University, USA \\ Tony L Henthorne, $\mathrm{PhD}^{* *}$ \\ University of Nevada Las Vegas, USA \\ Alvin J Williams, $\mathrm{PhD}^{* * *}$ \\ University of South Alabama, USA
}

\begin{abstract}
In the present research, Stanley Plog's (1967) Psychocentrism - Allocentrism Visitation Model is reimagined. The researcher decomposes Plog's original model and identifies five smaller bell shaped curves constituting five tourist personas within the normal distribution of tourist flow that depicts Plog's model. The study also finds that, while allocentric tourists largely prefer nascent destinations, destinations that are close to the end of their life cycles become attractive to them once again.
\end{abstract}

Keywords: tourist persona, allocentric, midcentric, psychocentric, Plog, destination marketing.

\section{Introduction}

Plog's psychographic typology of destination visitation schematizes the distribution of tourists to a destination and their psychographic profiles on a time scale (Plog, 1974, 1990, \& 2002). Just as the tourism area life cycle model that came after it (Butler, 1980), Plog's model proposed a near normal distribution of visitation across a time scale. According to Plog, tourists to a destination exhibit personality types along a continuum from those exhibiting extreme allocentrism at the beginning of a destination's life cycle to those exhibiting extreme psychocentrism at the end of the life cycle. Litvin (2006) notes that Plog began his investigations on tou- rist psychographics in the 1960's and thus is a pioneer in modeling the tourist persona.

When a destination is nascent, it is visited by tourists who can be broadly classified as allocentrics - novelty seekers who want to see and do new things and explore the world. They tend to be self-confident, anxiety-free, and like to travel especially to exotic or very unique destination areas. Psychocentrics, the last wave of tourists to a 'destination in its demise', are self-inhibited, nervous, non-adventuresome, and are familiarity seeking individuals. They show territory boundedness, generalized anxieties, and a sense of powerlessness. Plog classified the majority of tourists in between as midcentrics who shared borders with near psychocentrics and near allo-

* Associate Professor of Business / Services Area Alaska Pacific University, USA. E-mail: bgeorge@alaskapacific.edu ** Professor and Associate Dean of Tourism University of Nevada Las Vegas, USA. E-mail: tony.henthorne@unlv.edu

*** Distinguished Professor of Marketing University of South Alabama, USA. E-mail: awilliams@usouthal.edu 
centrics (Plog, 1990). It must be noted that Plog was not the only researcher who tried to classify tourists based on psychographics. Some other noteworthy attempts include classifications based on involvement (Fesenmaier \& Johnson, 1989), risk behavior (Reisinger \& Mavondo, 2005), destination attachment (George, 2005), sensationalism (Pomfret, 2006), nativistic motive (George, Inbakaran, \& Poyyamoli, 2010), attitude towards social responsibility (Gramann, Bonifield, \& Kim, 1995), and intrinsic vs. extrinsic motive (Iwasaki \& Mannell, 1999).

Thanks to the intuitive appeal of Plog's model for a nascent discipline like tourism that was searching for determinacy in its early days of development, it gained instant popularity. In fact the growth in its popularity corresponded well with the surging popularity for psychographics in the consumer literature during the 70's and 80's. Later researchers tried to empirically verify the model; some succeeded (Albanese, 1996), some did not succeed at all (Smith, 1990), while some others achieved partial success (Litvin, 2006). Despite this flux, the model continues to be taught in graduate schools and is widely referred to as one of the foundational theories of tourism. The intent of this paper is to attempt a bottom up reconstruction of Plog's model to better understand how the interactions among its constituents determine visitation patterns across a destination's life cycle. The refined model that we propose offers better predictive power and thus would help to alleviate some of the major criticisms against the original model.

\section{Standing upon plog's shoulders - but, moving beyond}

It cannot be left unnoticed that Plog's classification closely resembles the diffusion of innovation theory developed by Rogers (1962). Rogers proposed a scheme of innovation adopter categorization which included innovators, early adopters, early majority, late majority, and laggards (Figure 1). While Plog might have adapted elements of Roger's theory, for some strange reason, Plog and the researchers came after him preferred to depict tourist types as a continuum from psychocentric to allocentric (Figure 2) which led many to mistake that the psychocentrics as a group chronologically preceded allocentrics.

Since the overall distribution of tourist numbers to a destination as given by Plog's model is bell shaped, and because the normal distribu-

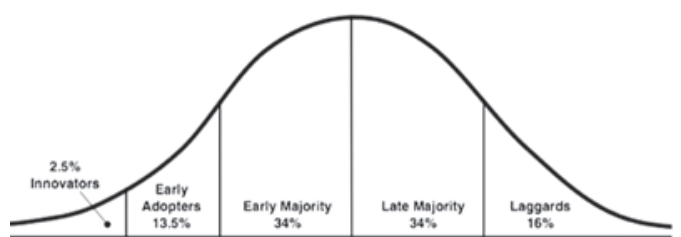

Figure 1: Roger's theory of diffusion of innovations

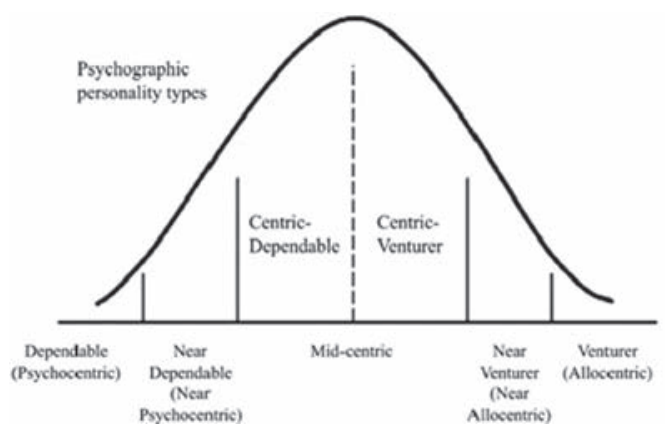

Figure 2: Plog's traveler personality typology

tion approximates most natural phenomena very well, it is reasonable to argue that individual segments (such as allocentric, near allocentric, mid centric, near psychocentric, and psychocentric) that together constitute the distribution each can also be described with bell curves. The mathematical-probabilistic basis for this comes from Cramer's decomposition theorem (LevyCramer theorem), according to which a normal distribution is infinitely divisible into smaller normal distributions (Gut, 2005).

Cramer's decomposition theorem states that if $X$ and $Y$ are independent real random variables and if $(X+Y)$ follows normal distribution, then both $X$ and $Y$ are normally distributed. Applying induction, if any finite sum of independent real-valued random variables is normal, then the summands must all be normal. Superimposition of the aforesaid onto Plog's original graphical depiction would result in a new model as follows (Figure 3).

We propose that the revised model approximated above is a more realistic depiction of tourist demographics in a destination at any moment in time. Unlike the original depiction, it does not assume that the transition from one segment to the other happens instantaneously. The revised model also gives provision for the coexistence of more than one segment. Even though a normal distribution never touches the horizontal axis, the number of observations 


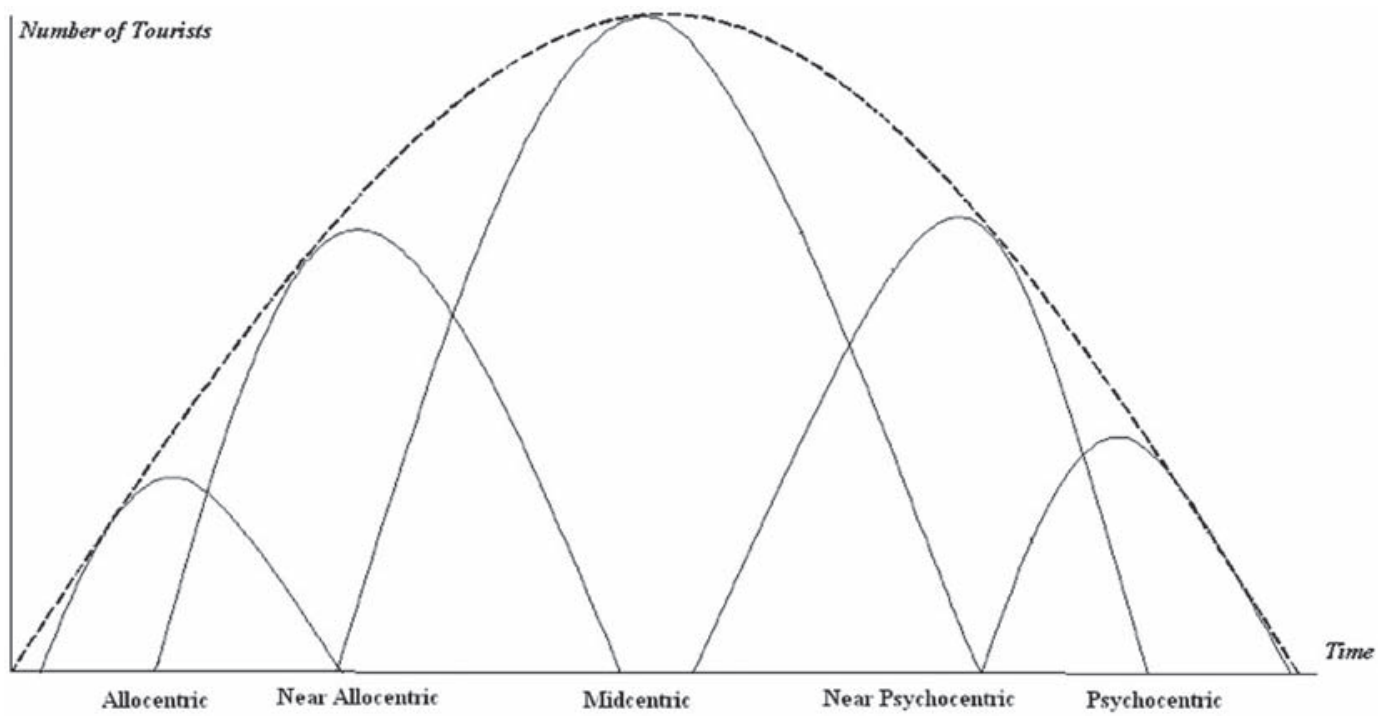

Figure 3: The modified Plog model (George Model)

towards the extremes tends to become negligible and hence the graph is shown as if it touches the horizontal axis. Finally, on a time scale, it clearly shows that allocentrics precede psychocentrics, rather than the other way round in Plog's original depiction.

\section{The study}

Our attempt is to validate the proposed model by mapping the sequence of appearance of the psychological segments in a destination with corresponding stages in the destination area life cycle. To do this, we examined five different tourism destinations: a discovery stage destination (Vagamon, Kerala, India); a growing destination (Wayanad, Kerala, India); a maturing destination (Alleppey, Kerala, India); a matured destination (Thekkady, Kerala, India); and a decli- ning destination (Thrissur, Kerala, India). These choices were informed by the available trends in tourist visitation but constrained by the resource limitations of the researcher. Available data about the different accommodation and transportation types, the types of restaurants and their prices, etc., helped us to form a priori guesses about the life cycle position of these destinations. Data for the study was collected by the first author of this paper during NovemberDecember 2011. Slightly modified versions of the five personality questions originally used by Plog (1974) to measure the allocentric-psychocentric continuum were used to survey tourists visiting each of these destinations. In total, 293 tourists were interviewed and the cross tabulation of the responses are summarized in table 1:

The data presented above does reveal a pattern for the naked eye, somewhat close to what is predicted by our model. To better understand

Table 1: Destination type - Tourist Psychography cross tabulation

\begin{tabular}{|c|c|c|c|c|c|c|c|}
\hline & \multicolumn{5}{|c|}{ Tourist psychographic type } & \multirow[b]{2}{*}{ Total } \\
\hline & & Allocentric & $\begin{array}{c}\text { Near } \\
\text { Allocentric }\end{array}$ & Mid-Centric & $\begin{array}{c}\text { Near } \\
\text { Psychocentric }\end{array}$ & Psychocentric & \\
\hline \multirow{5}{*}{$\begin{array}{l}\text { Destination } \\
\text { lifecycle stage }\end{array}$} & Discovery & 19 & 11 & 7 & 9 & 6 & 52 \\
\hline & Growing & 13 & 20 & 13 & 7 & 5 & 58 \\
\hline & Maturing & 6 & 12 & 24 & 11 & 11 & 64 \\
\hline & Matured & 9 & 7 & 13 & 20 & 19 & 68 \\
\hline & Declining & 12 & 6 & 3 & 6 & 24 & 51 \\
\hline \multicolumn{2}{|l|}{ Total } & 59 & 56 & 60 & 53 & 65 & 293 \\
\hline
\end{tabular}


the nuances of relationships, multinomial logistic regression analysis was performed. Multinomial logistic regression is used to predict the probability of category membership on a dependent variable based on multiple independent variables. In order to do this, five dummy variables were generated out of the categorical variable 'destination lifecycle stage', each representing a stage in the lifecycle. The multinomial regression was executed with the 'declining' as the referencing variable and the model summary is given in table 2 .

According to theory, for better fit, indices should be lower for the full model than it is for the null model. This condition is satisfied with a statistical significant at $\mathrm{p}<0.01$. The analysis revealed statistically significant levels of
Table 2: Multinomial regression model summary

\begin{tabular}{|l|c|c|c|c|}
\hline \multicolumn{1}{|c|}{ Model } & $\begin{array}{c}\text { Model } \\
\text { Fitting } \\
\text { Criteria }\end{array}$ & \multicolumn{3}{|c|}{ Likelihood Ratio Tests } \\
\hline & $\begin{array}{c}-2 \text { Log } \\
\text { Likelihood }\end{array}$ & $\begin{array}{c}\text { Chi- } \\
\text { Square }\end{array}$ & df & Sig. \\
\hline Intercept Only & 143.294 & & & \\
\hline Final & 75.071 & 68.223 & 16 & .000 \\
\hline
\end{tabular}

pseudo $\mathrm{R}^{2}$ scores (Cox and Snell=0.208; Nagelkerke $=0.216$ ) and likelihood ratios. The model parameter estimation summary is presented in table 3. The classification efficiency of the model may be seen in table 4 .

Table 3: Model parameter estimation w.r.t. declining destination category

\begin{tabular}{|c|c|c|c|c|c|c|c|c|c|}
\hline \multirow{2}{*}{\multicolumn{2}{|c|}{ Destination lifecycle stage ${ }^{a}$}} & \multirow[b]{2}{*}{$\mathrm{B}$} & \multirow[b]{2}{*}{ Std. Error } & \multirow[b]{2}{*}{ Wald } & \multirow[b]{2}{*}{ df } & \multirow[b]{2}{*}{ Sig. } & \multirow[b]{2}{*}{$\operatorname{Exp}(B)$} & \multicolumn{2}{|c|}{$\begin{array}{l}95 \% \text { Confidence Interval for Exp } \\
\text { (B) }\end{array}$} \\
\hline & & & & & & & & Lower Bound & Upper Bound \\
\hline \multirow[t]{6}{*}{ Discovery } & Intercept & -1.386 & .456 & 9.225 & 1 & .002 & & & \\
\hline & $\begin{array}{l}\text { Tourist Psychographic_ } \\
\text { Type=1.00] }\end{array}$ & 1.846 & .587 & 9.896 & 1 & .002 & 6.333 & 2.005 & 20.003 \\
\hline & $\begin{array}{l}\text { [Tourist Psychographic_ } \\
\text { Type=2.00] }\end{array}$ & 1.992 & .683 & 8.520 & 1 & .004 & 7.333 & 1.924 & 27.945 \\
\hline & $\begin{array}{l}\text { [Tourist_Psychographic_ } \\
\text { Type }=3.00]\end{array}$ & 2.234 & .827 & 7.288 & 1 & .007 & 9.333 & 1.844 & 47.237 \\
\hline & $\begin{array}{l}\text { [Tourist Psychographic_ } \\
\text { Type }=4.00]\end{array}$ & 1.792 & .697 & 6.604 & 1 & .010 & 6.000 & 1.530 & 23.530 \\
\hline & $\begin{array}{l}\text { [Tourist Psychographic_ } \\
\text { Type }=5.00 \text { ] }\end{array}$ & $0^{\mathrm{b}}$ & . & . & 0 & . & . & . & . \\
\hline \multirow[t]{6}{*}{ Growing } & Intercept & -1.569 & .492 & 10.182 & 1 & .001 & & & \\
\hline & $\begin{array}{l}\text { [Tourist Psychographic_ } \\
\text { Type=1.00] }\end{array}$ & 1.649 & .634 & 6.763 & 1 & .009 & 5.200 & 1.501 & 18.015 \\
\hline & $\begin{array}{l}\text { [Tourist_Psychographic_ } \\
\text { Type }=2.00]\end{array}$ & 2.773 & .677 & 16.772 & 1 & .000 & 16.000 & 4.245 & 60.310 \\
\hline & $\begin{array}{l}\text { TTourist_Psychographic_ } \\
\text { Type }=3.00]\end{array}$ & 3.035 & .807 & 14.129 & 1 & .000 & 20.800 & 4.274 & 101.237 \\
\hline & $\begin{array}{l}\text { [Tourist_Psychographic_ } \\
\text { Type=4.00] }\end{array}$ & 1.723 & .742 & 5.385 & 1 & .020 & 5.600 & 1.307 & 23.996 \\
\hline & $\begin{array}{l}\text { [Tourist Psychographic_ } \\
\text { Type }=5.00 \text { ] }\end{array}$ & $0^{b}$ & . & . & 0 & . & . & . & . \\
\hline \multirow[t]{6}{*}{ Maturing } & Intercept & -.780 & .364 & 4.591 & 1 & .032 & & & \\
\hline & $\begin{array}{l}\text { [Tourist Psychographic_ } \\
\text { Type }=1.00 \text { ] }\end{array}$ & .087 & .619 & .020 & 1 & .888 & 1.091 & .325 & 3.667 \\
\hline & $\begin{array}{l}\text { [Tourist Psychographic_ } \\
\text { Type=2.00] }\end{array}$ & 1.473 & .619 & 5.674 & 1 & .017 & 4.364 & 1.298 & 14.667 \\
\hline & $\begin{array}{l}\text { [Tourist_Psychographic_ } \\
\text { Type }=3.00]\end{array}$ & 2.860 & .712 & 16.111 & 1 & .000 & 17.455 & 4.320 & 70.525 \\
\hline & $\begin{array}{l}\text { [Tourist Psychographic_ } \\
\text { Type }=4.00 \text { ] }\end{array}$ & 1.386 & .625 & 4.926 & 1 & .026 & 4.000 & 1.176 & 13.606 \\
\hline & $\begin{array}{l}\text { [Tourist Psychographic_ } \\
\text { Type=5.00] }\end{array}$ & $0^{b}$ & . & . & 0 & . & . & . & . \\
\hline \multirow[t]{6}{*}{ Matured } & Intercept & -.234 & .307 & .579 & 1 & .447 & & & \\
\hline & $\begin{array}{l}\text { Tourist Psychographic_ } \\
\text { Type }=1.00 \text { ] }\end{array}$ & -.054 & .537 & .010 & 1 & .920 & .947 & .330 & 2.716 \\
\hline & $\begin{array}{l}\text { [Tourist Psychographic_ } \\
\text { Type }=2.00]\end{array}$ & .388 & .635 & .372 & 1 & .542 & 1.474 & .424 & 5.121 \\
\hline & $\begin{array}{l}\text { [Tourist_Psychographic_ } \\
\text { Type }=3.00]\end{array}$ & 1.700 & .710 & 5.727 & 1 & .017 & 5.474 & 1.360 & 22.024 \\
\hline & $\begin{array}{l}\text { [Tourist_Psychographic_ } \\
\text { Type }=4 . \overline{0} \text { ] }\end{array}$ & 1.438 & .558 & 6.646 & 1 & .010 & 4.211 & 1.411 & 12.560 \\
\hline & $\begin{array}{l}\text { [Tourist Psychographic_ } \\
\text { Type }=5.00 \text { ] }\end{array}$ & $0^{b}$ & . & . & 0 & . & . & . & . \\
\hline
\end{tabular}

a. The reference category is: Declining.

b. This parameter is set to zero because it is redundant. 
Table 4: Summary of right-wrong classifications by the model

\begin{tabular}{lrrrrrr}
\hline Observed & \multicolumn{6}{c}{ Predicted } \\
\cline { 2 - 7 } & Discovery & Growing & Maturing & Matured & Declining & $\begin{array}{c}\text { Percent } \\
\text { Correct }\end{array}$ \\
\hline Discovery & 19 & 11 & 7 & 9 & 6 & $36.5 \%$ \\
Growing & 13 & 20 & 13 & 7 & 5 & $34.5 \%$ \\
Maturing & 6 & 12 & 24 & 11 & 11 & $37.5 \%$ \\
Matured & 9 & 7 & 13 & 20 & 19 & $29.4 \%$ \\
Declining & 12 & 6 & 3 & 6 & 24 & $47.1 \%$ \\
Overall Percentage & $20.1 \%$ & $19.1 \%$ & $20.5 \%$ & $18.1 \%$ & $22.2 \%$ & $36.5 \%$ \\
\hline \hline
\end{tabular}

This table shows which of the tourist psychographic categories significantly distinguish the declining stage from other stages in the destination area life cycle. The results are mixed, making interpretations difficult. Yet, table 4 indicates that the proposed model is largely useful: it correctly predicted $36.5 \%$ of the observations. Particularly in the case of declining destinations, the prediction came right $47.1 \%$ of times.

For a discerning observer, a surprising configuration that emerges from the data is that allocentric explorers find destinations in decline quite attractive. Recall that the descriptive summary presented in table 1 showed that 12 of the 51 tourists we interviewed in a declining destination were allocentric individuals. Graphical depiction of cross tabulation with interpolation lines given in figure 3 makes the patterns more evident and the same is provided in figure 4 .

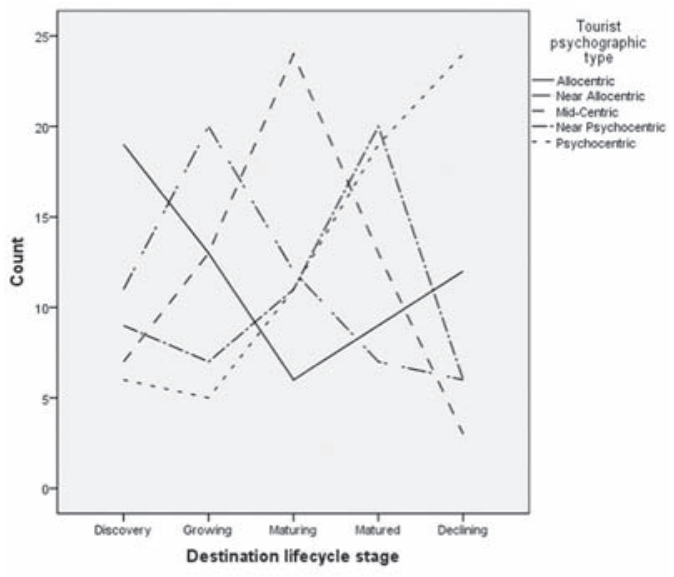

Figure 4: The distribution of psychographic segments along destination area life cycle
Irrefutable empirical support for the new model should come from a mixed model analysis of the longitudinal data collected continuously across the full life cycles of a number of diverse destinations. This is an extremely arduous task and even the original Plog model has not been subjected to such a test. Until then, the assumption of normality of particular psychographic segments within the Plog model will likely remain to be a postulate whose truth will at best be judged by means of indirect outcomes.

\section{Conclusion}

This study attempts to better understand the sub-structures of the destination visitation model developed by Stanley Plog (1974). The findings generally reaffirm the belief that the laws of the natural world resonate with those of the human world. At a more pragmatic level, it helps practitioners, especially destination management organizations, to better understand visitation dynamics. It refines and extends Plog's original model, the result of which is a more robust model with substantially improved predictive power. In terms of refining an existing theory in the tourism social science literature, it is just an incremental contribution. However, the contribution may be viewed as radical if we look at the value addition brought in by relating a fundamental mathematical-statistical theorem with the extant nomological network of tourism.

It is true that our observations do not fit perfectly with either Plog's basic model or our improved model. That said, the data supports the broad patterns predicted by the models. Can we conclude that this is yet another evidence for the fact that the laws of the mathematical world are largely applicable in the worlds of behavioral and social sciences as well? Aside 
from the fact the data does not offer any near perfect fit, many assumptions are made while trying to superimpose the theoretical model upon data. For instance, a key assumption held by Crammer's theorem is that the summands are independent. However, according to some researchers, tourists could simultaneously be allocentric, midcentric, and psychocentric; they might liminally transit from one profile to the other; and the same destination might simultaneously be catering to multiple segments (Crossley \& Jamieson, 1999; Lowyck, Van Lagenhove, \& Bollaert, 1993; McKercher, 2005; Park, S. Tussyadiah, I. P. Mazanec, J. A. \& Fesenmaier, 2010). If this is so, the assumption of independence is violated.

While we do not have definitive answers, an important question for future research does emerge in our minds: do declining destinations at least partially exhibit characteristics of new destinations that are in the discovery stage? If our choice of destinations is truly representative and if the observed pattern is not spurious, it might as well be so. It is quite logical to argue that when the mainstream 'mob of tourists' abandons declining destinations they might regain a charm long lost. Re-branding messages aimed at destination rejuvenation might amplify the element of nostalgia which is a driver for reexploration among the allocentrics. Destination management organizations are charged with the fundamental mission of understanding the tourists visiting their destinations better (Miguens \& Mendes, 2008) and hence they have an added incentive to utilize this insight to gain increased tourist satisfaction and loyalty.

One of the central theses of the present investigation is that destinations do not age in discreet fashion - nor does the patronization of psychographic segments change instantaneously. At any point in time, a destination is more than likely be visited by multiple segments. The bell curves within the big bell curve actually overlap a lot. As we have seen, the curve for allocentric tourists sees resurgence when the destination is under decline. Naïve destination managers who fail to see this microscopic picture might be missing important relationshipprofit opportunities. From a slightly different perspective, this is an encouraging thought for businesses: there is always scope for niche marketing to some of these minority segments. That makes more sense especially for those in the SME sector who cannot afford the cost of a radical reconfiguration of products and services.

What most researchers would agree about Plog's original model is that it has only limi- ted scope as a managerial decision support tool (Abbey, 1979; Chon \& Sparrowe, 2000; Litvin, 2006; Albanese, 1996). With the extra insights that we gained from the present study, this criticism has to be alleviated to a great extent. More analysis using multiple datasets collected from a diverse range of destinations is needed to see if the characteristics of a normal curve will provide clues about the characteristics of the succeeding normal curves. If questions like whether the parameters of the normal curve associated with allocentrics could help predict the parameters of, say, the normal curve associated with near midcentrics can be answered, the revised model will acquire the characteristics of a much needed predictive model of tourist behavior.

The perpetual shrinking of product life cycles is something uniquely characterizing our economy and society. Products are introduced and they become overnight sensations - but they become extinct equally fast. While one might wonder if product life cycle studies like the one we have just undertaken might have any lasting relevance, we would want to align with the other side: the very phenomenon of shortening and increasingly unpredictable life cycles make examining and reexamining them even more important. We wind up this manuscript by consecrating it to the loving memory of the great visionary tourism thinker Stanley Plog who departed on us 16 February 2011 and upon whose insights parts of the foundational structures of tourism theory are laid.

\section{References}

Abbey, J.

1979 "Does life style profiling work?". Journal of Travel Research, 18(1): 8-14.

Butler, R.

1980 "The Concept of a Tourist Area Life Cycle: Implications for Management of Resources". Canadian Geographer, 24: 5-12.

Chon, K.S. \& Sparrowe, R.T.

2000 Welcome to Hospitality: An Introduction (2nd edn), Albany: Delmar Thomson Learning.

Crossley, J. C. \& Jamieson, L. M.

1999 Introduction to Commercial and Entrepreneurial Recreation. Champaign, IL: Sagamore Publishing.

Fesenmaier, D. R. \& Johnson, B.

1989 "Involvement based segmentation: Implications for travel marketing in Texas". Tourism Management, 10(4): 293-300. 
George, B.P.

2005 "Measuring tourist attachment to holidays: Some preliminary results". Tourism: An International Interdisciplinary Journal, 52(3): 229-246.

George, B.P. Inbakaran, R., \& Poyyamoli, G.

2010 "To travel or not to travel: Towards understanding the theory of nativistic motivation". Tourism: An International Interdisciplinary Journal, 58(4): 395-407.

Gramann J. H., Bonifield, R. L., \& Kim, Y.

1995 "Effect of personality and situational factors on intentions to obey rules in outdoor recreation areas". Journal of Leisure Research, 27(4): 326-343.

Gut, A.

2005 Probability: A Graduate Course. New York: Springer-Verlag.

Iwasaki, Y., \& Mannell, R. C.

1999 "Situational and personality influences on intrinsically motivated leisure behavior: Interaction effects and cognitive processes". Leisure Sciences, 21: 287-306.

Litvin, S. W.

2006 "Revisiting Plog's model of allocentricity and psychocentricity: One more time". Cornell Hotel and Restaurant Administration Quarterly, 47(3): 245-253.

Lowyck, E., Van Langenhove, L., \& Bollaert, L.

1993 Choice and Demand in Tourism, Johnson, P. and Tomas, B. (Eds). London: Mensell Publishing.

McKercher, B.

2005 "Are Psychographics Predictors of Destination Life Cycles?" Journal of Travel \& Tourism Marketing, 19(1): 49-55.

Miguens, J. I. L., \& Mendes, J. F. F.

2008 "Travel and tourism: Into a complex network". Physics and Society, 387(12): 29632971.

Park, S., Tussyadiah, I. P., Mazanec, J. A., \& Fesenmaier, D. R.

2010 "Travel Personae of American Pleasure Travelers: A Network Analysis". Journal of Travel \& Tourism Marketing, 27(8): 797-811.

Plog, S.C.

1974 "Why destinations areas rise and fall in popularity". Cornell Hotel and Restaurant Administration Quarterly, November, 13-16.

Plog, S. C.

1990 "A Carpenter's Tools: An answer to Stephen LJ Smith's review of psychocentrism/ allocentrism". Journal of Travel Research, 28(4): 43-45.
Plog, S. C.

2002 "The power of psychographics and the concept of venturesomeness". Journal of Travel Research, 40: 244-251.

Pomfret, G.

2006 "Mountaineering adventure tourists: A conceptual framework for research". Tourism Management, 27: 113-123.

Reisinger, Y., \& Mavondo, F.

2005"Travel anxiety and intentions to travel internationally: Implications of travel risk perception". Journal of Travel Research, 43: 212-225.

Rogers, E.

1964 Diffusion of Innovations. New York: Glencoe Free Press

Smith, S. L. J.

1990 "A Test of Plog's allocentric/psychocentric model: Evidence from seven nations". Journal of Travel Research, 28(4): 40-43.

Recibido:

$24 / 04 / 2013$

Reenviado:

$15 / 05 / 2013$

Aceptado:

$01 / 07 / 2013$

Sometido a evaluación por pares anónimos 